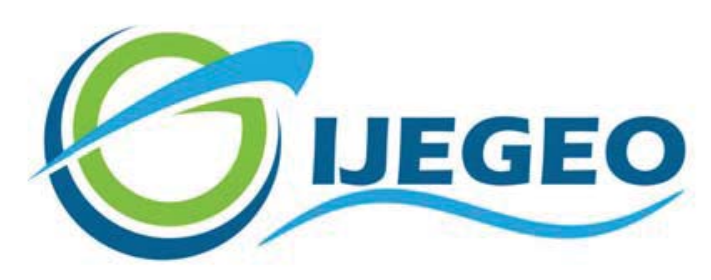

International Journal of Environment and Geoinformatics (IJEGEO) is an international, multidisciplinary, peer reviewed, open access journal.

\title{
Underwater Excavation at the Basilica Church in İznik Lake - 2019
}

\section{Miustafa ŞAHIN}

\section{Chief in Editor}

Prof. Dr. Cem Gazioğlu

Co-Editors Prof. Dr. Dursun Zafer Şeker, Prof. Dr. Şinasi Kaya,

Prof. Dr. Ayşegül Tanık and Assist. Prof. Dr. Volkan Demir

Editorial Committee (June 2022)

Assoc. Prof. Dr. Abdullah Aksu (TR), Assoc. Prof. Dr. Uğur Algancı (TR), Assoc. Prof. Dr. Aslı Aslan (US), Prof. Dr. Levent Bat (TR), Prof. Dr. Paul Bates (UK), İrşad Bayırhan (TR), Prof. Dr. Bülent

Bayram (TR), Prof. Dr. Luis M. Botana (ES), Prof. Dr. Nuray Çağlar (TR), Prof. Dr. Sukanta Dash (IN), Dr. Soofia T. Elias (UK), Prof. Dr. A. Evren Erginal (TR), Assoc. Prof. Dr. Cüneyt Erenoğlu (TR), Dr. Dieter Fritsch (DE), Prof. Dr. Ç; Prof. Dr. Manik Kalubarme (IN), Dr. Hakan Kaya (TR), Assist. Prof. Dr. Serkan Kükrer (TR), Assoc. Prof. Dr. Maged Marghany (MY); Prof. Dr. Micheal Meadows (ZA), Prof. Dr. Nebiye Musaoğlu (TR), Prof. Dr. Masafumi Nakagawa (JP), Prof. Dr. Hasan Özdemir (TR), Prof. Dr. Chyssy Potsiou (GR), Prof. Dr. Erol Sarı (TR), Prof. Dr. Maria Paradiso (IT), Prof. Dr. Petros Patias (GR), Prof. Dr. Elif Sertel (TR), Prof. Dr. Nüket Sivri (TR), Prof. Dr. Füsun Balık Şanlı (TR), Dr. Duygu Ülker (TR), Prof. Dr. Seyfettin Tsaş (TR), Assoc. Prof. Dr. Ömer Suat Taşkın (TR), Assist. Prof. Dr. Tuba Ünsal (TR), Assist. Prof. Dr. Sibel Zeki (TR) 


\title{
Research Article
}

\section{Underwater Excavation at the Basilica Church in İznik Lake - 2019*}

\author{
Mustafa Şahin (iD \\ Bursa Uludağ University, Faculty of Arts and Sciences, Archaeology Department, 16240, Nilüfer-Bursa/Turkey. \\ * Corresponding author: Name Surname \\ Received: 04.09.2020 \\ E-mail: mustafasahin@uludag.edu.tr \\ Accepted 1.10.202 \\ How to cite: Şahin (2020). Underwater Excavation at the Basilica Church in İznik Lake - 2019, International Journal of Environment and \\ Geoinformatics (IJEGEO), 9(2). 071-080. doi. 10.30897/ijegeo.790313
}

\begin{abstract}
The ancient city of Nikaia is well known in Christian circles as the place from which an early and important statement of faith was issued: The Nicene Doctrine. The remains of the basilica church were discovered approximately in 2 or 3 meters of depth, and $50 \mathrm{~m}$ from the shore of the İznik Lake, outside the city walls that surround the ancient city of Nikaia in 2014. Excavation questions include to whom the structure was dedicated, why and when the church was demolished and submerged under the waters of the lake. In 2019, excavation was carried out in the atrium where we thought a water well was situated. This is because the British pilgrim, Willibald, pointed out that the site of the 1st Council had a rectangular open roofed courtyard with a sacred source of oil in the middle. Although we went down $60 \mathrm{~cm}$ deeper than the foundation walls, we could not find the bottom of the well. It was also found that the well was filled with stone. Therefore, we think that the structure was abandoned in the approximately 13th century A.D. and then sank into the lake waters.
\end{abstract}

Keywords: Nikaia, İznik Lake, Basilica Church, Neophytos, First Council.

* The format is arranged in accordance with the notion of the Archeology profession.

\section{Introduction}

The ancient city of Nikaia is well known in Christian circles as the place from which an early and important statement of faith was issued: The Nicene Doctrine (Davis 1990). The remains of the basilica church lie approximately in 2 or 3 meters of depth, and $50 \mathrm{~m}$ from the shore of the lake, outside the city walls that surround the ancient city of Nikaia (Powell 2015, 27; Şahin and Fairchild 2018) (fig. 1). The underwater archaeological excavations at the basilica remains is being launched under the auspices of the Iznik Archaeology Museum with the permission of the Ministry of Culture and Tourism in 2015 .

Excavation questions include to whom the structure was dedicated, why and when the church was demolished and submerged under the waters of the lake. we have three hypotheses through the underwater excavations. One of our three hypotheses is that this church could belong to St. Neophytos. Our other hypothesis that the church could be built on the foundations of the lost Apollo temple. Our other hypothesis is whether the church could be built on the foundations of the lost Apollo temple. The final hypothesis is that the Senate Palace, where the First Council meets, is located in this structure. The purpose of the excavations is to determine the construction plan of the basilica and its surrounding ruins, and excavations continue within a predetermined schedule. In this article will be primarily emphasized the hypothesis whether the 1st ecumenical council was convened here or not.
Considering the location of the structure, it appears that it was an extramural church on the shore of the lake. Therefore, there might be a church complex in this location (fig. 2). The remains can be considered to have belonged to a basilica- plan church based on its east/west axis, rectangular plan, has three naves and an apse on the eastern section.

The basilica is located at the center of the remains with three naves and in the east-west direction (fig. 2). At the northern part lies, diaconicon with the sarcophagus was composed of separate parts. The northern wall of the room is diagonal (fig. 3).

\section{Materials and Methods}

One of our three hypotheses is that the Senate Palace, where the First Council meets, is located in this structure. As known, the First Council of Nikaia in 325 was depicted in the fresco in the Sistine Chapel in the Vatican (Cappella Sistina) (Veth 2003, 295-306 Pl. 6; Şahin 2015, 49 fig. 19). The meeting place of the First Council, which is recognized by all four major denominations in Christianism, remains unknown. Above-mentioned fresco depicts the council meeting along with the building. Although the fresco was dated to 1590 , the depiction of the landscape from a window on the left corner make the fresco interesting for our study. Based on the landscape, it appears that the meeting was held in an extramural building and by the İznik Lake, which shares similarities with the building we are going to excavate. 


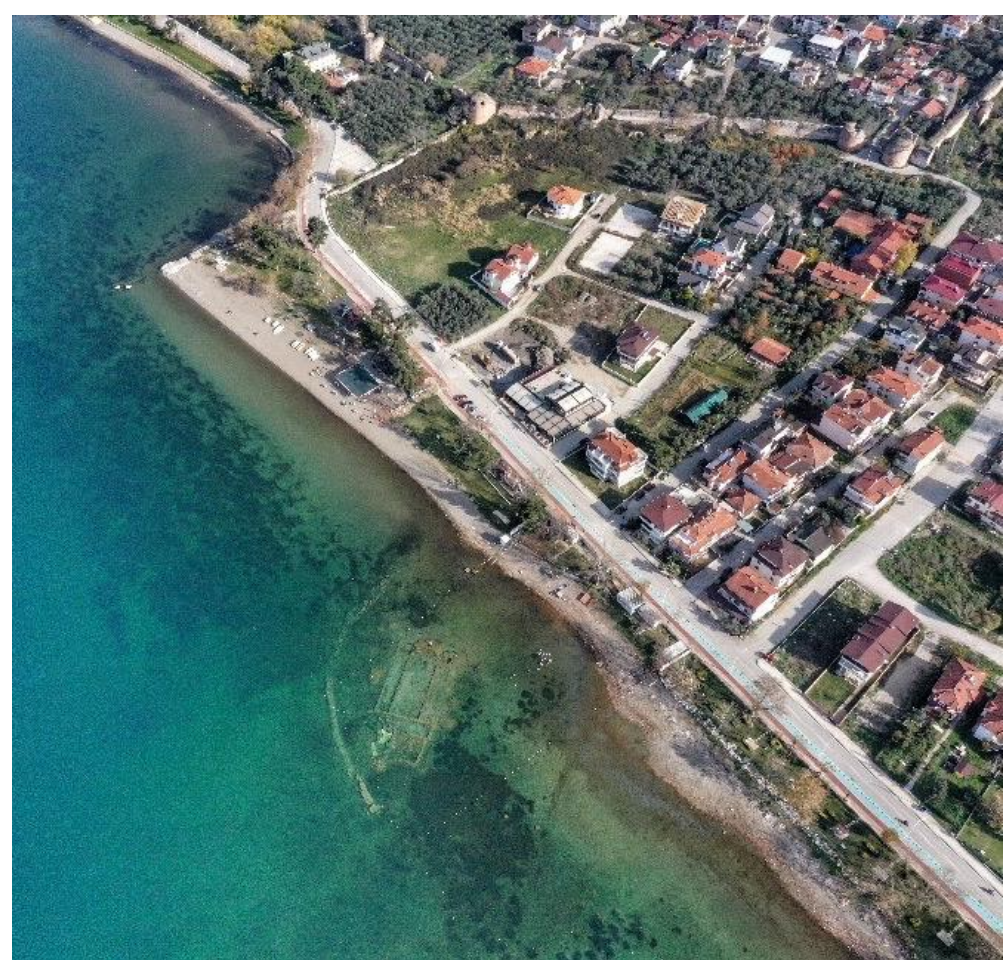

Fig. 1. Drone photo of the shore at Iznik Lake.

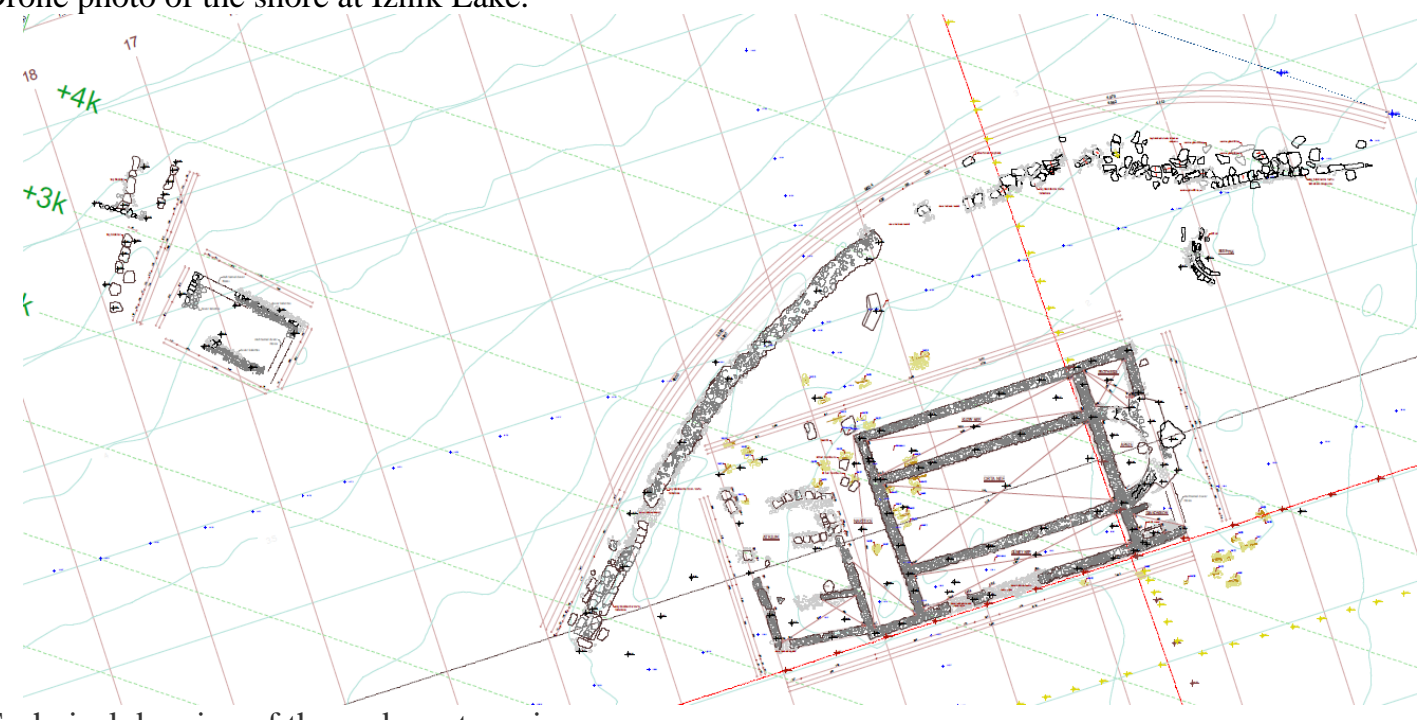

Fig. 2. Technical drawing of the underwater ruins.

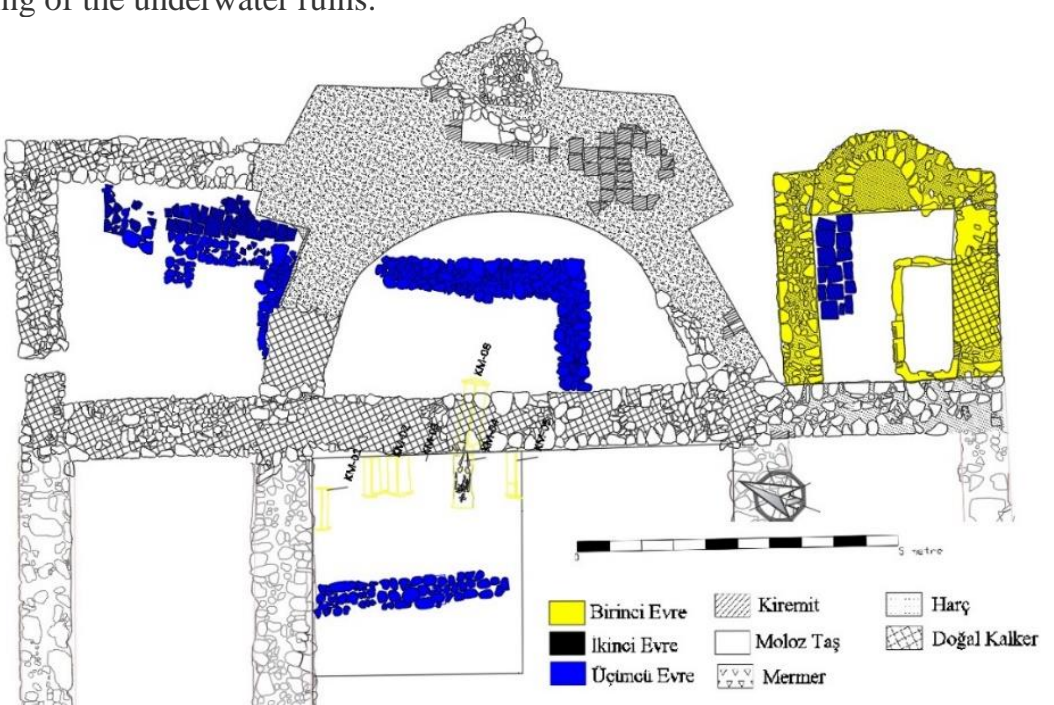

Fig. 3. Technical drawing with color coding showing different phases of the church. 
We obtain information about the architecture of the structure where the 1st Council was gathered from a British pilgrim named Willibald (727-729) (Mango 2004). Willibald likens the church to the church on Mount Olives, where Jesus ascended to heaven, and furthermore, he says that there are depictions of the bishops who joined the Council. He also states that the upper part of the church is open, there is a bronze altar in the middle and there is a candle in a glass lantern to burn it in all weather conditions. John Covel, who visited the site in 1675 , mentions that there is a small gate protected

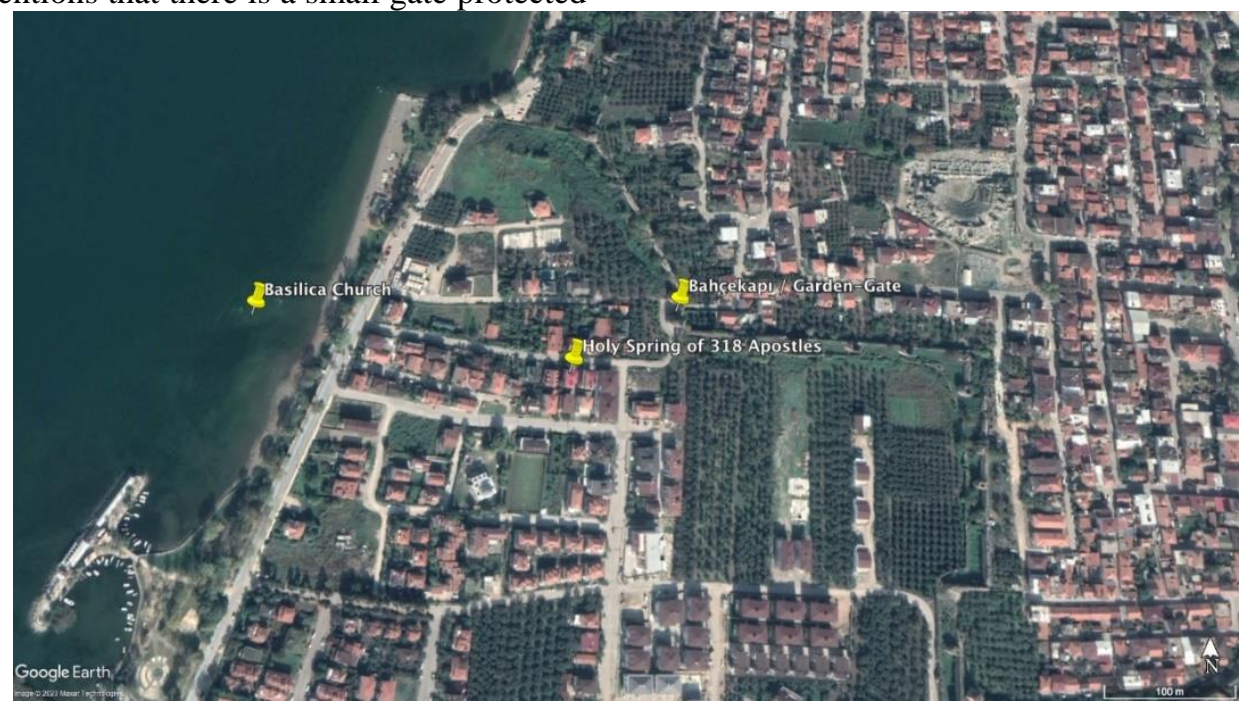

Fig. 4. Depicting the area on a map at the holy spring of 318 Apostle.

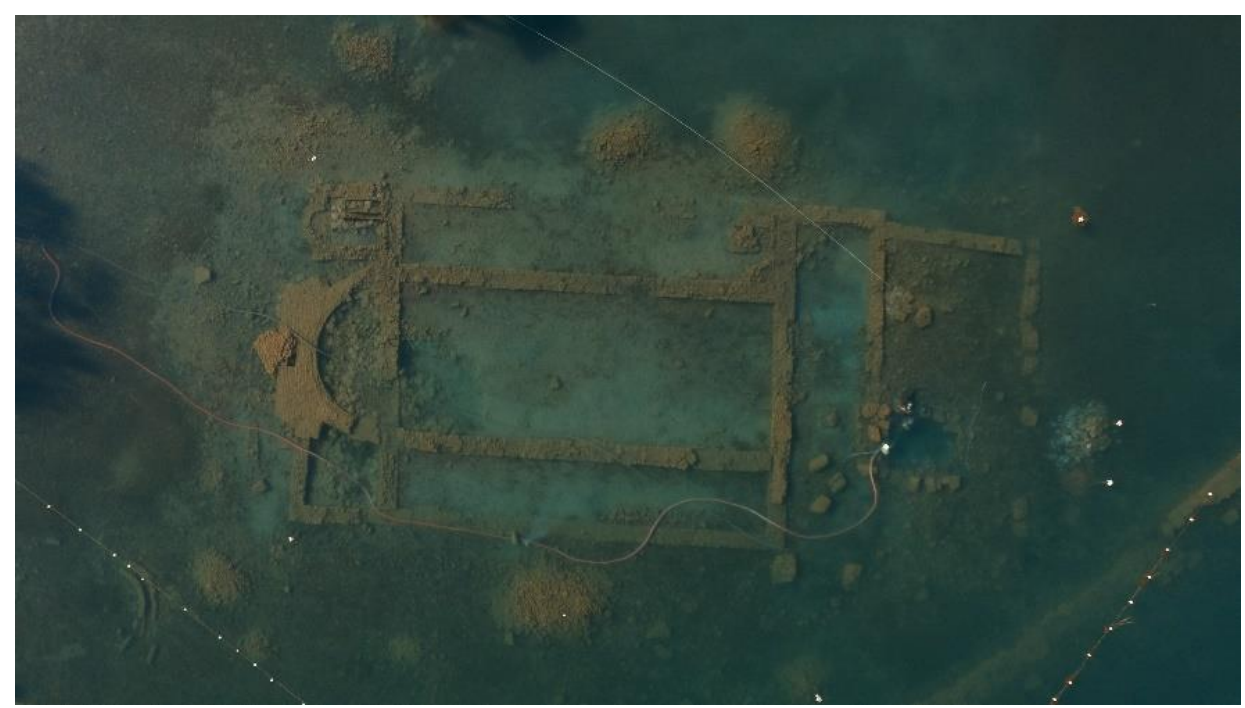

Fig. 5. Aerial image of Basilica Church.

\section{Results}

As far as we have learned from Willibald (727-729), the place where the 1st Ecumenical Consul was gathered is an open hall, and there is a well or pool shaped structure in which the sacred oil is extracted (Mango 2004, 305306). Based on this information, the possibility occurred that the area surrounded by monolithic stones in the section we call the atrium could be a well (fig. 5). For this reason, the excavations in 2019 were shifted to the sounding area, which we marked with the number 12 by two towers called Bahçekapı (garden-gate) between the Göl-Gate and the Yenişehir-Gate (Covel 1998; Yildirım 2014-II). In the meadow in front of the gate, the Turks gather in Ramadan and worship. At the foot of the walls, there is a holy spring called " 318 Apostles" by the Greeks (fig. 4). The aforementioned gates and holy spring were found in our researches in 2019. The fact that the name of the holy spring is 318 apostles and its proximity to our basilica may be another sign that the Palace of the Council will be here. 


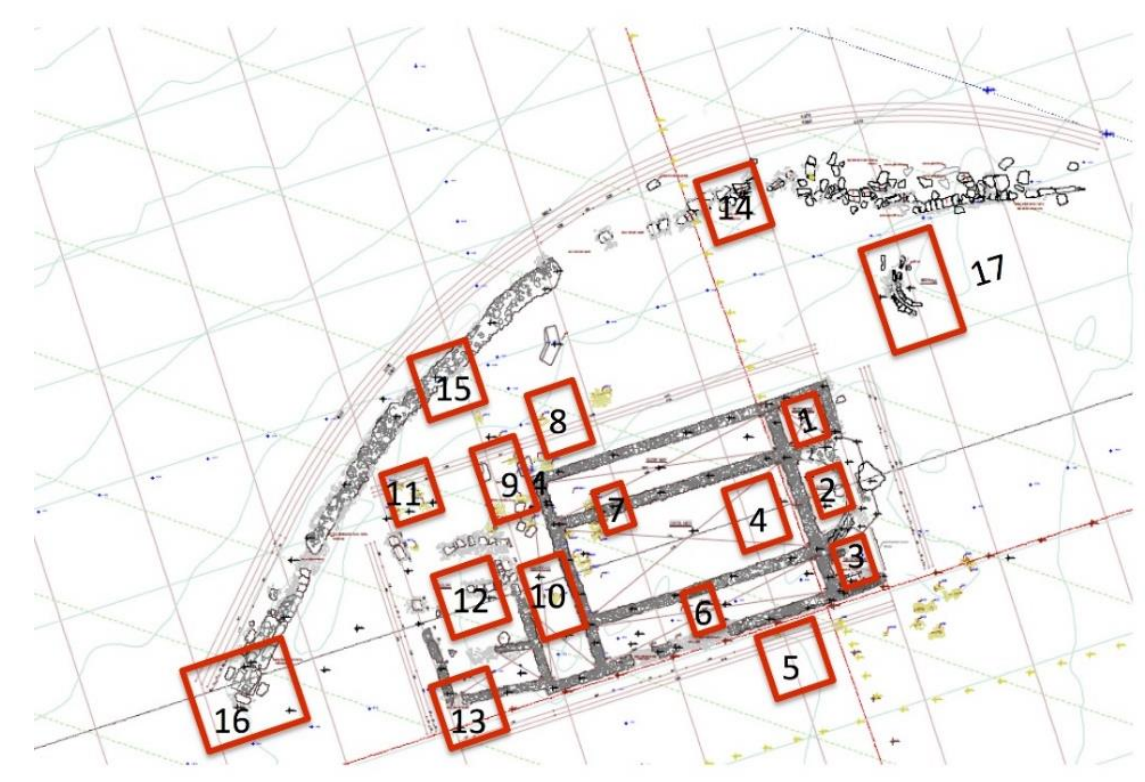

Fig. 6. Sounding areas on the ruin.

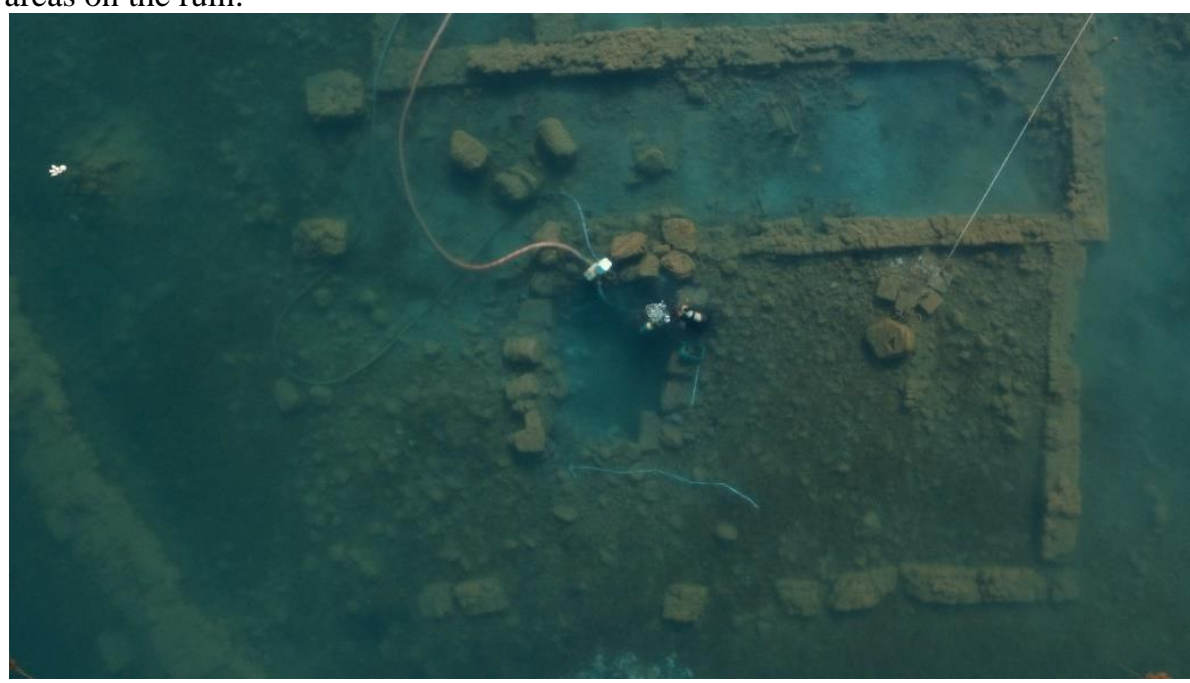

Fig. 7. Aerial image of atrium.

Since the excavation season is ending, excavations were suspended without going down to this level with the idea of not damaging the wooden girders. The level will be excavated during dies excavation season (fig. 7). During the excavations, 82 coins were found. 37 of these coins belong to the Late Byzantine Period, known as the scyphate coins and used between $11-13$ centuries AD, one of which is silver and the other 36 coins are bronze. Coins point to a wide range of time periods from the forth (fig. 8)1 to the thirteenth century (fig. 9)2. The

\footnotetext{
${ }^{1}$ Helena, AE Follis, AD 328-329, 2,5 gr, 18,3 mm. Obv: FL HELENA- AVGVSTA, diademed and draped bust right, the tiara is formed from a row of beaded medallions, around the neck, a pearl necklace.

Rev: SECVRITAS- REI PVBLICE / SMANT, Securitas standing left, holding olive branch in extended right hand and lifting the edge of her dress. RIC VII, 190.

${ }^{2}$ Theodore I, AE, AD 1208-1222, 1,9 gr, 23,8 mm.
}

majority of the ceramics found to consist of fine ceramics (fig. 10)3. It was determined that they were generally produced between the eleventh and thirteenth centuries (fig. 11)4. Among the metal works, the density consists of nails of different sizes (fig. 12). Glass pieces belonging to bracelets and vessels are also among the finds (fig. 13).

Obv: $\Theta E O \Delta O$, St. Theodore standing front, holding spear and resting hand on shield.

Rev: Theodore, crowned and wearing loros, standing front, holding sceptre and cross on globe. DOC IV, 466 Kat. 11.2 Pl. 28.

${ }^{3}$ Trefoil-mouth jug (mastrapas), handle and part of the mouth are missing, $H: 14.5 \mathrm{~cm}$, rim diameter: $5 \mathrm{~cm}$, foot diameter: $5 \mathrm{~cm} .7,5 Y R 5 / 3$ brown and 7,5YR8/1 white slip painted ware.

${ }^{4}$ Bowl, base and part of body preserved, $H: 5,5 \mathrm{~cm}$, diameter: $12,5 \mathrm{~cm}$, foot diam. $4,1 \mathrm{~cm}$. Interior covered with $10 Y R 5 / 6$ yellowish brown and 10YR 2/2 very dark brown glaze. 13 . century AD. Papanikola-Bakirtzis 1999, 218 Kat. 252. Inanan 2014, $149 \mathrm{Pl}$. 1-f. 

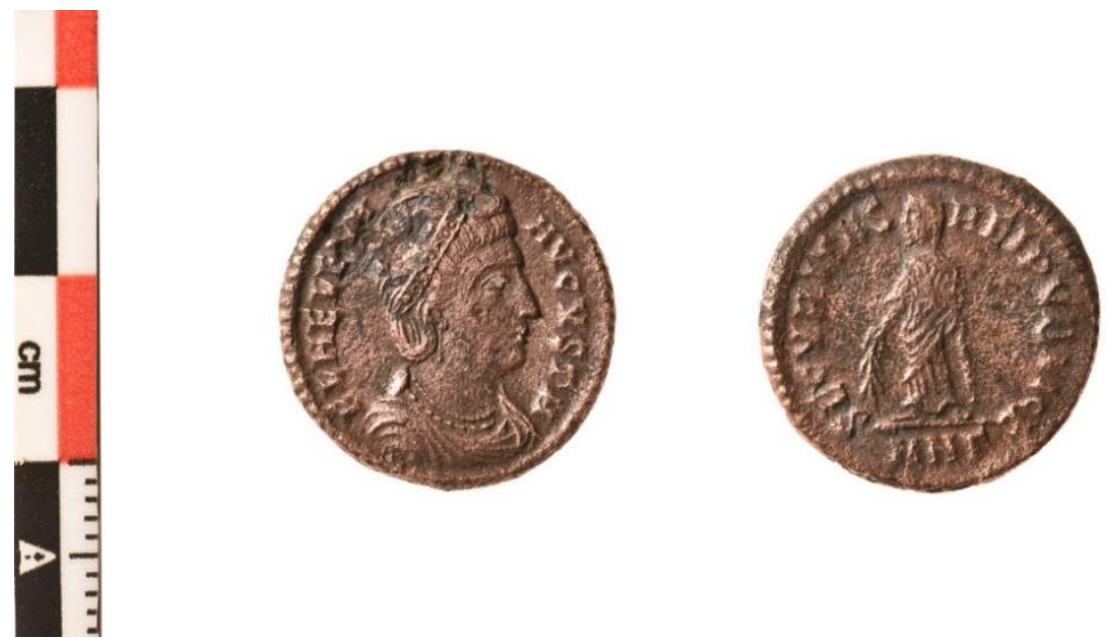

Fig. 8. AE Follis of Helena. AD 328 - 329.
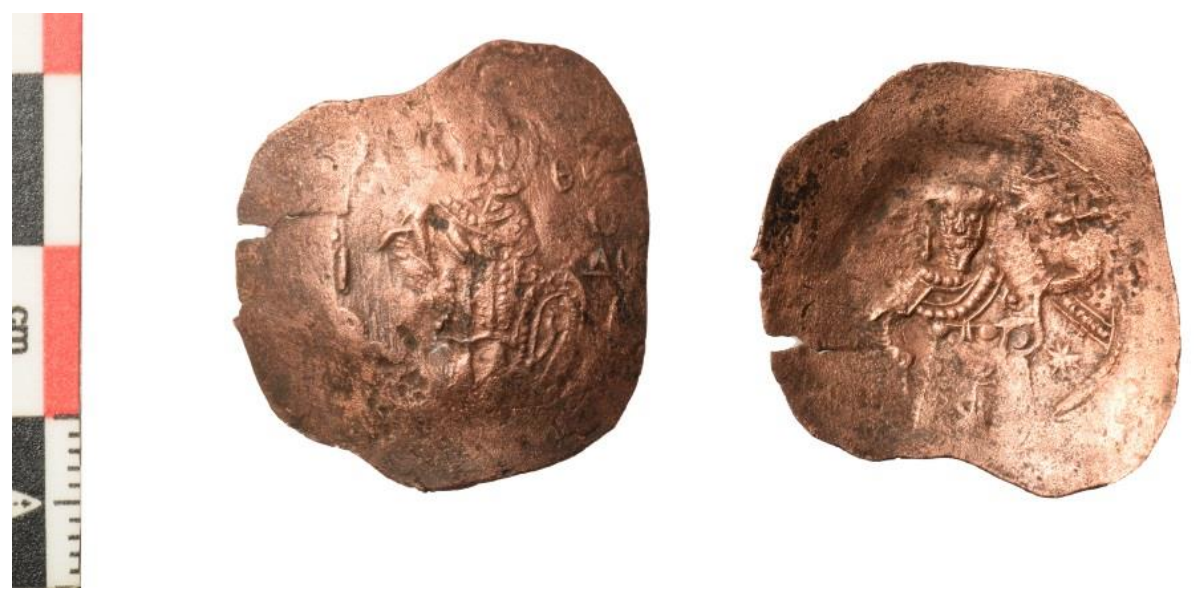

Fig. 9. Scyphate AE coins of Theodore I, AD 1208-1222.
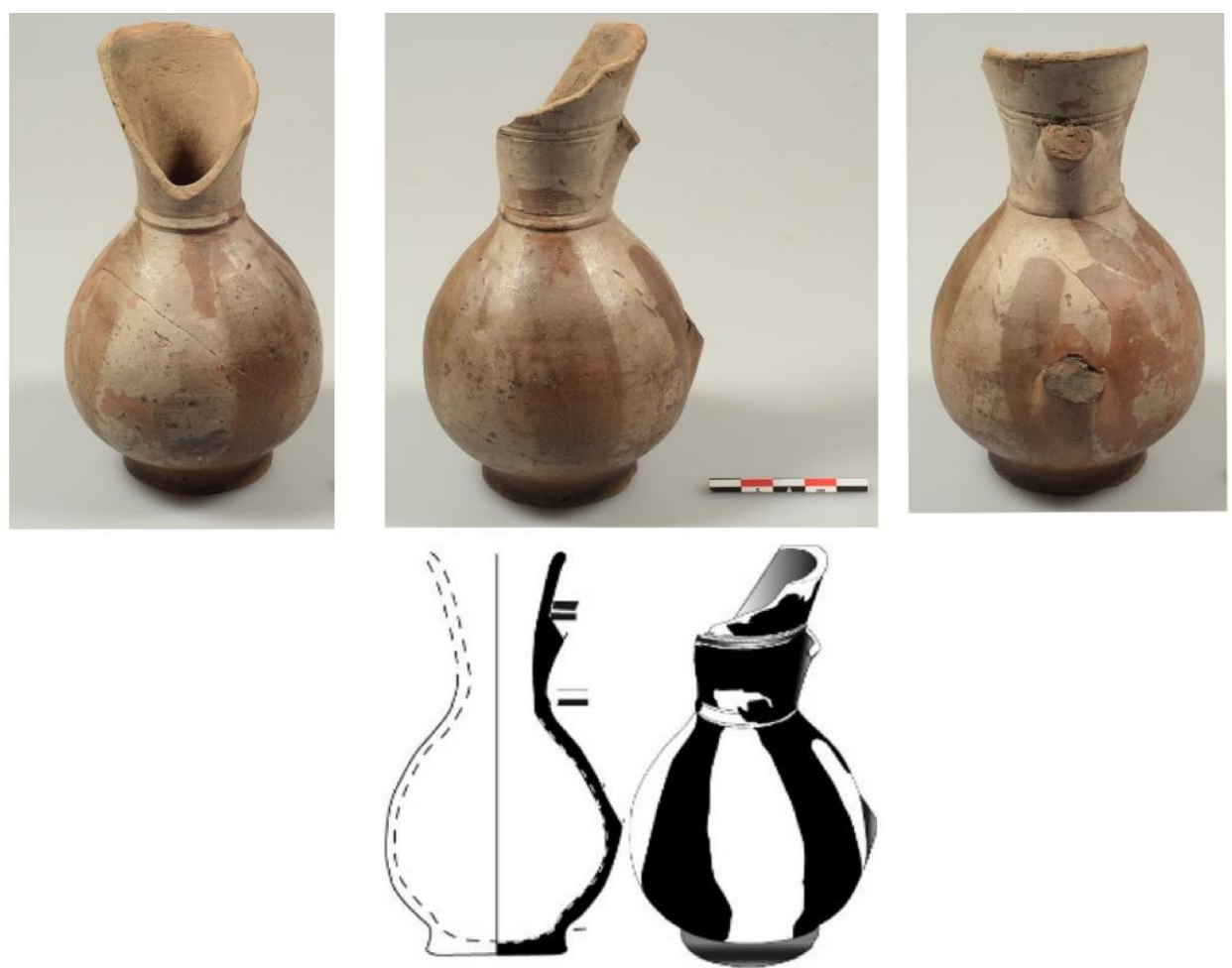

Fig. 10. Ceramic Jar between the 11 th and 13th centuries A.D. 


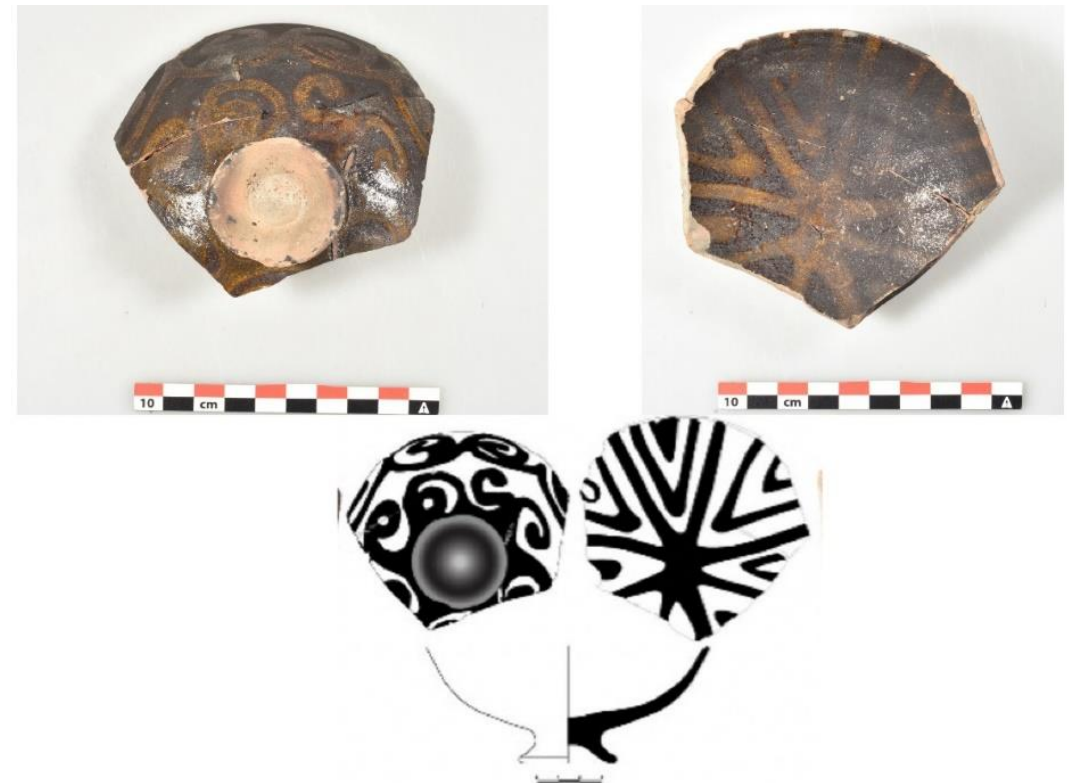

Fig. 11. Piece of fine ceramics between the 11th and 13th centuries A.D.

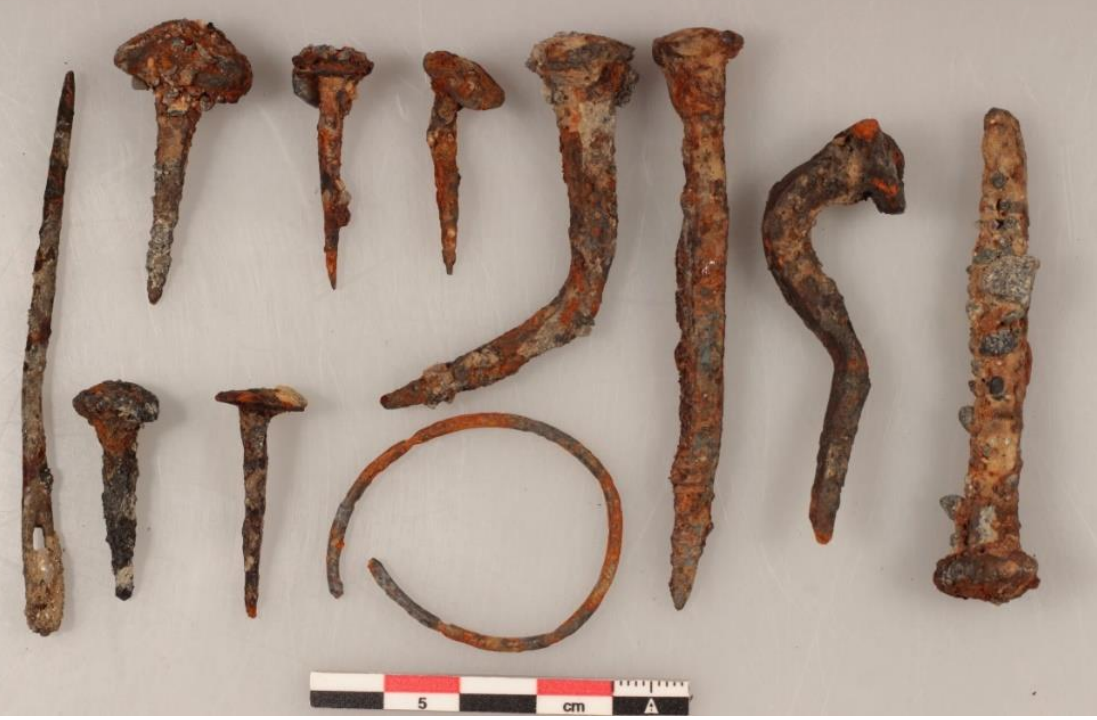

Fig. 12. Iron nails of different sizes.

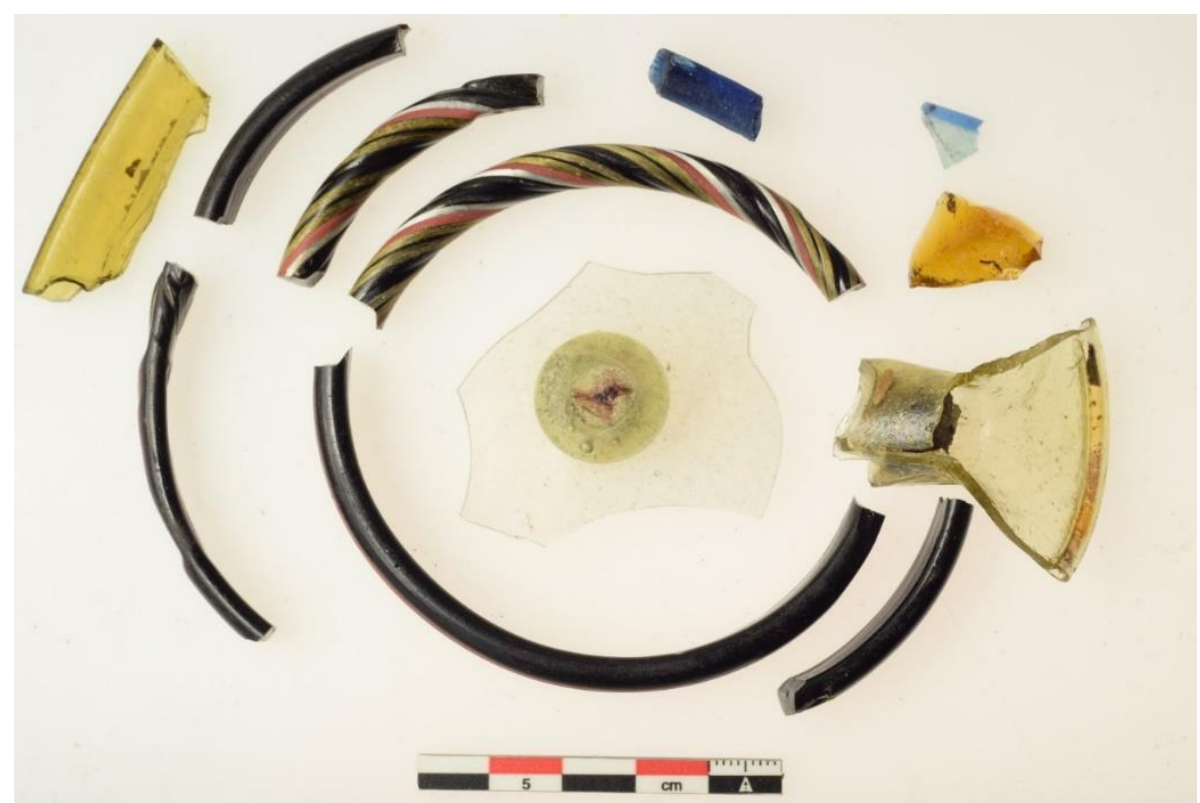

Fig. 13. Pieces of glass. 


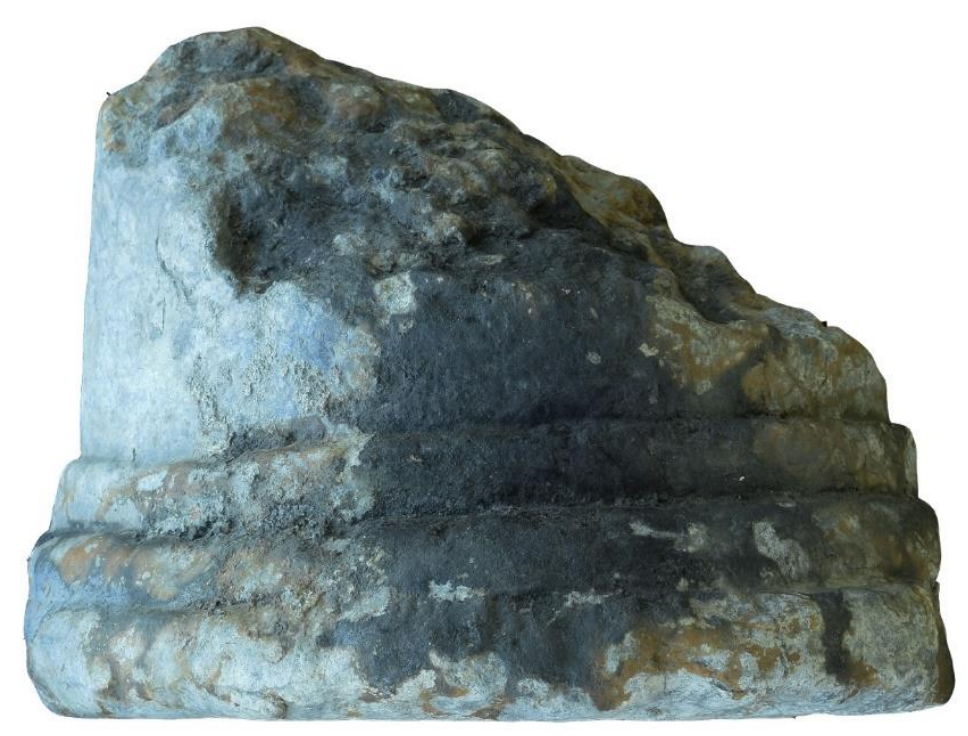

Fig. 14. Piece of colonnettes.
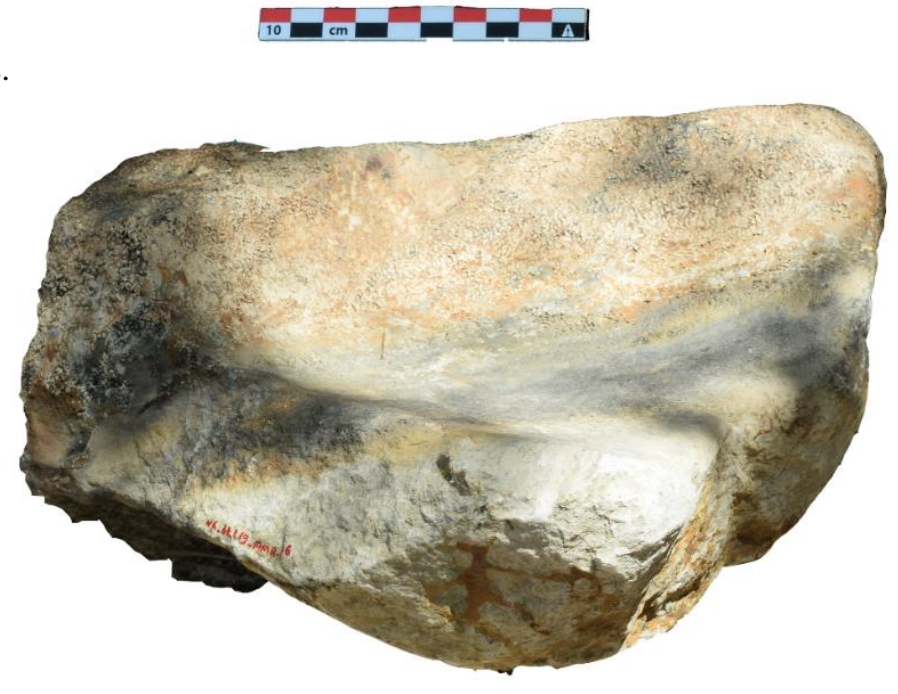

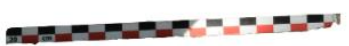

Fig. 15. Piece of baptistery.
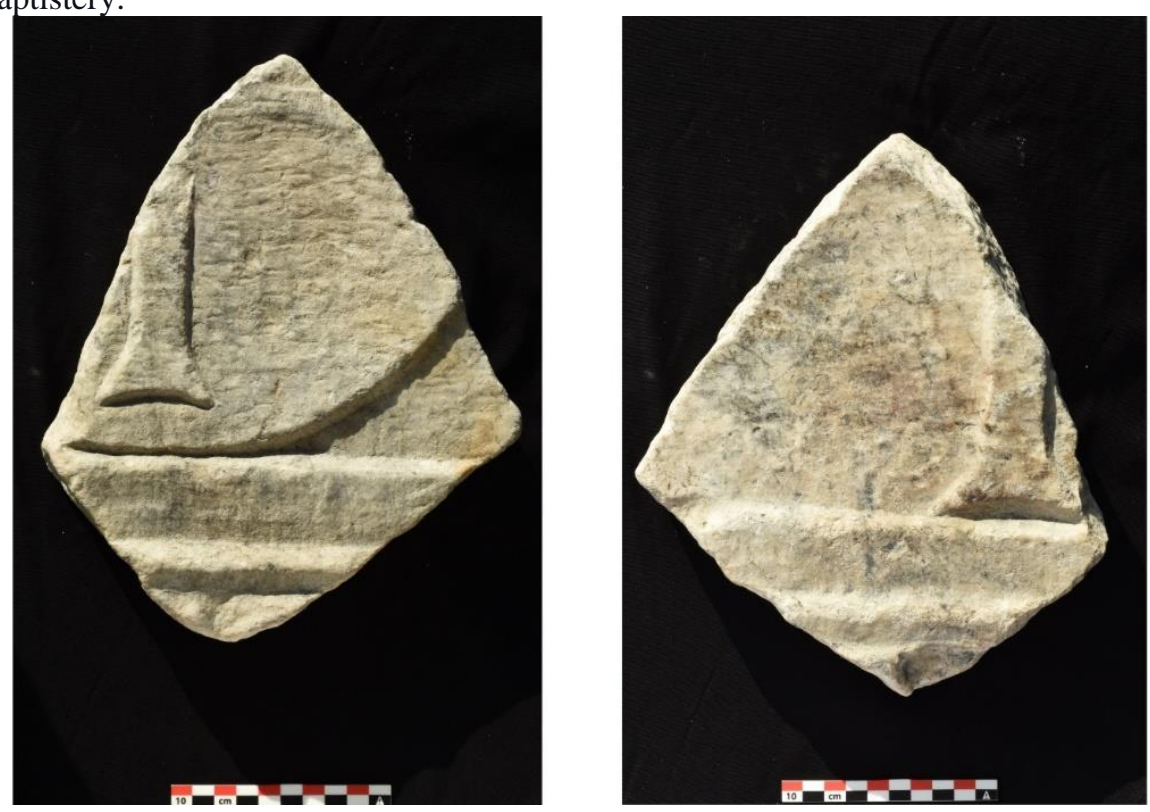

Fig. 16. Piece of Ambon. 


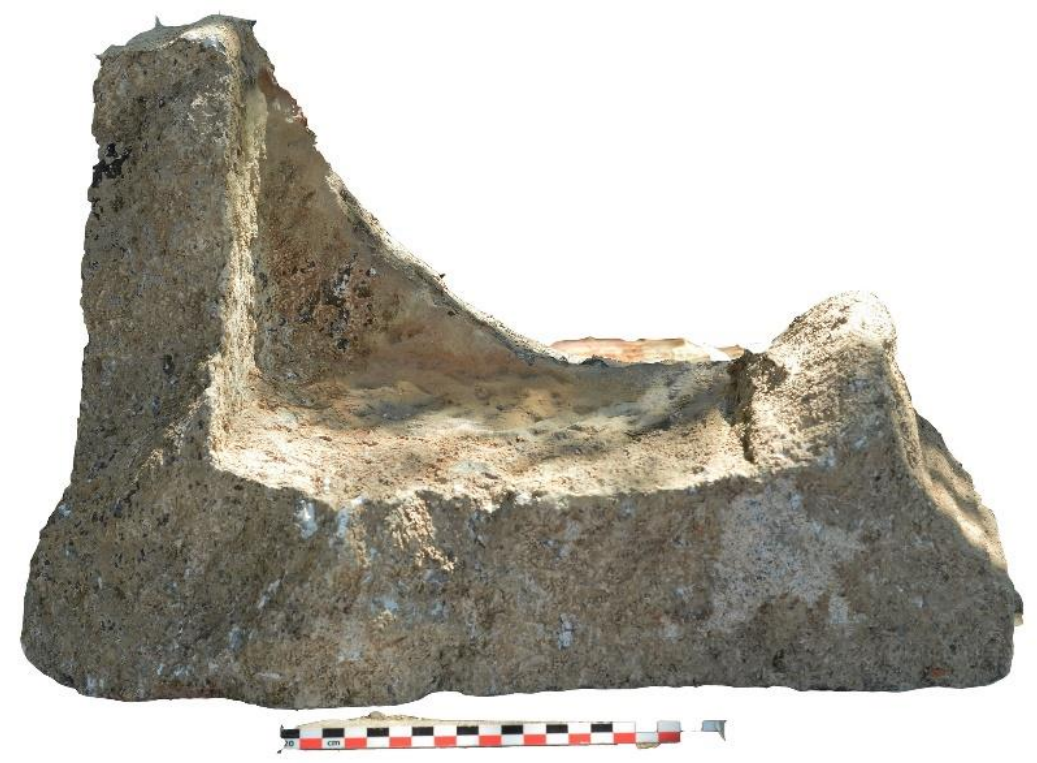

Fig. 17. Piece of osthotek.

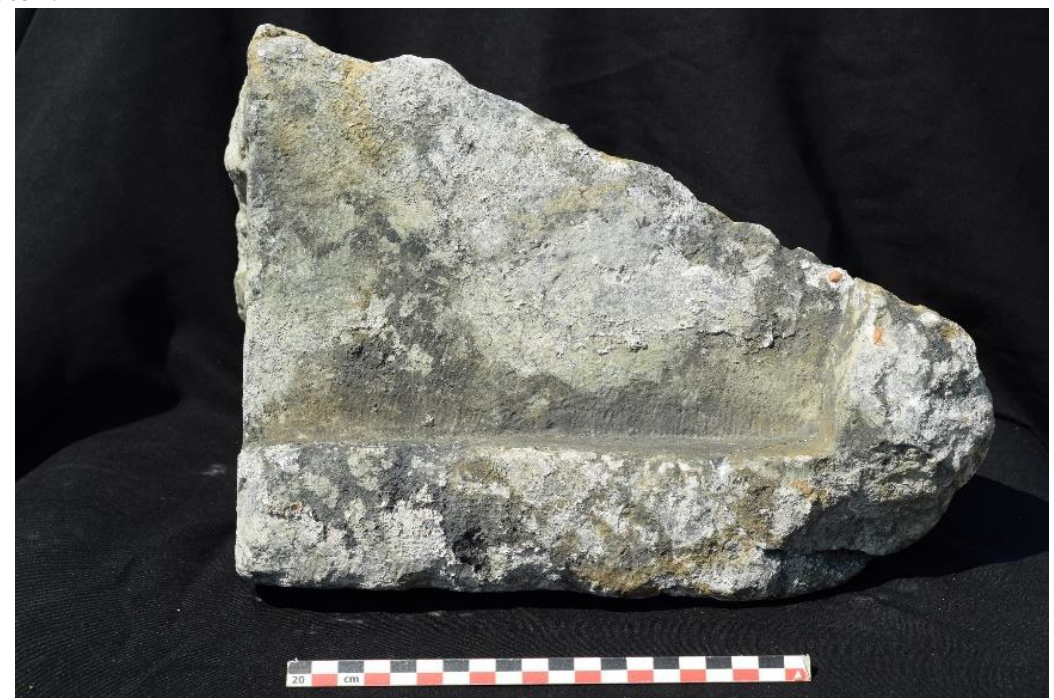

Fig: 18. Piece of grave stele.

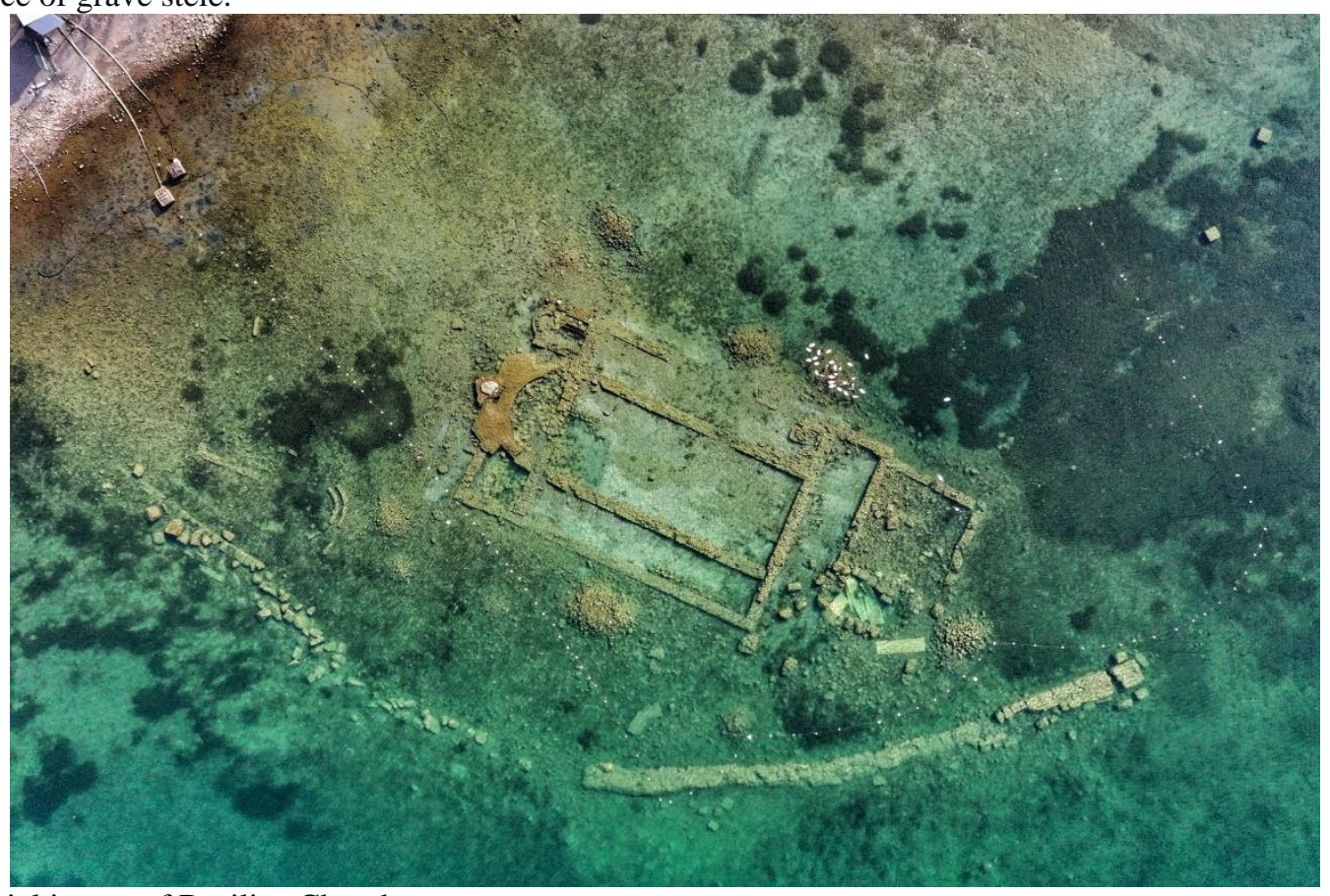

Fig. 19. Aerial image of Basilica Church. 
In addition to rubble stones, there are many fragmented marble and stone artefacts in the filling material. For example, piece of colonnettes (fig. 14)5, piece of baptistery (fig. 15)6 or ambon (fig. 16)7, piece of osthotek (fig. 17)8 or grave stele (fig. 18)9 etc.

We have concluded that during the excavations carried out in the apse, diaconicon, and pastaphoria sections between 2015 and 2018, the area was mostly looted, and therefore no stratigraphy can be mentioned. However, for the first time in the sounding trench $12 \mathrm{~A}$, an area that was not touched after abandonment and thus gave stratigraphy started to be excavated. During the excavations in 2019, tips were obtained about the last use of the building and that it might have been sank in the 13th century AD. This layer affected by this deformation is dated at 1010/1182 A.D. that coincides with the well documented $1065 \mathrm{AD}$ earthquake (Ambraseys 2009; Gastineau et al. 2021) and agrees with an archeo-seismological study documenting the destruction-reconstruction phases of Iznik buildings between 715 and 1097 AD (Benjelloun 2018; Erginal et al. 2021). According to the original historical archive, the $1065 \mathrm{AD}$ earthquake has strongly damaged the Iznik city (formerly Nicaea/ Nikaia): "It happened at Nikaia in Bithynia and brought almost total devastation and ruin to the place. Its most important and large churches [...] and the one of the Holy Fathers, where the Council of the most Holy and Orthodox Fathers against Areios confirmed its decisions [...] those churches, then, were shaken and collapsed as did the walls of the city along with many private dwellings" (Michael and Attaleiatēs 2012). No other locality seems to have been damaged such as Iznik during this earthquake. The ca. $50 \mathrm{~cm}$ vertical co-seismic offset could have triggered a destructive wave (tsunami) or a lake-level variation that led to the destruction and submersion of the basilica of Nikaia explaining why this basilica has been then never rebuilt (Şahin 2014).

As the lakeshore approaches east of the basilica church, the lake level decreases. Especially in dry seasons, the tip of the apse goes out of the water and can be seen from the surface (fig. 19). This withdrawal in the lake waters must have caused the east parts of the building to be looted over time. Travellers who visit Iznik from time to time have not overlooked this looting, and they also included this issue in their notes. For example, Léon de Laborde, who visited Iznik in the 1830s, describes the looting in the ruins with the following sentences: "At the entrance to the city, we walked to the place where there was a strong wall descending towards the water in the south-west direction. There is a marsh area on the other side of this pier, which is the port where Alexius' navy carried victory to the crusaders by moving from Kios to

\footnotetext{
${ }^{5} \mathrm{H}: 16 \mathrm{~cm}$, diameter: $21 \mathrm{~cm}$.

${ }^{6} \mathrm{H}: 30 \mathrm{~cm}$, diameter: $68 \mathrm{~cm}$.

${ }^{7} \mathrm{H}: 21 \mathrm{~cm}$, length: 25,5, depth: $6 \mathrm{~cm}$,

${ }^{8} \mathrm{H}: 30,5 \mathrm{~cm}$, length: $48 \mathrm{~cm}$, depth: $29 \mathrm{~cm}$.

${ }^{9} \mathrm{H}: 24 \mathrm{~cm}$, length: $31 \mathrm{~cm}$.
}

Nikaia. In this closed area, the waters hit the bottom of the city walls. The archbishop gave us a Greek to guide the area. This antique dealer told us that the Consul church was located on the lakeshore near the pier outside the city walls. This is an old statement, and I read it in my guide book, Joseph von Hammer and Edris el Seadeddin confirms it. They stated that the ruins of a large city collapsed as a result of an earthquake in an arid and hot season appear in this area. In addition, divers pull kitchen equipment and metal furniture out of the water from this area. Nevertheless, without building high hopes, could these ruins belong to a long pier and the objects that the divers pull out of the water from the port structures? The question of the location of the consul church is still unknown" (Laborde 1838).

\section{Discussion and Conclusion}

In 2019, excavation was carried out in the atrium where we thought a water well was situated. This is because the British pilgrim, Willibald, pointed out that the site of the 1st Council had a rectangular open roofed courtyard with a sacred source of oil in the middle. Although we went down $60 \mathrm{~cm}$ deeper than the foundation walls, we could not find the bottom of the well. However, a large number of ceramics, glas bracelet or Scyphate coins (cup-shaped coins) were found indicating the 13 th century A.D. It was also found that the well was filled with stone. Therefore, we think that the structure was definitely abandoned in the approximately 13th century A.D. and then sank into the lake waters.

\section{Acknowledgements}

All photographs used in the article belong to the excavation archive, except figure 4, which is taken from google maps. The underwater excavations are carried out under the direction of the Directorate of İznik Museum on behalf of the Ministry of Culture \& Tourism. We are grateful to the Museum Director Mr. Ahmet Türkmenoğlu. Bursa Uludag University (Turkey) General Research Project Grant SGA-2021-389 (project title "Early Christian Martyriums in the Light of the Basilica Church of the Lake of Iznik" supports this project.

\section{Publications*}

Aktaş, G., Hisarli, Z.M., Demirel, A.S. (2021). Highresolution total field magnetic anomaly maps of Lake İznik (NW Turkey): assessment of faults which play important roles in tectonics of the lake. Mar Geophys Res 42,20.

Alpar B, Öztürk K, Adatepe F, Demirel S, Balkis N (2003) Sparker in lakes; reflection data from lake İznik. Turk J Mar Sci 9:195-207

Alpar, B., Güneysu, C. (1999) Evolution of the Hersek Delta (İzmit Bay). Turkish J Mar Sci 5: 57-74.

Ambraseys, N. (2009), Earthquakes in the Mediterranean and Middle East: A multidisciplinary study of seismicity up to 1900. Cambridge: 
Cambridge University Press. doi.0.1017/ CBO9781139195430

Ardel A (1954) İznik depresyonu ve gölü. İst Üniv Coğr Enst Dergisi (5-6): 225-229

Barış, Ş., Aydıngün, Ş., Kaya, H., Gazioğlu, C. (2021). Archeological Traces of Sixth Century Earthquakes in İstanbul Küçükçekmece Lake Basin (Bathonea) Excavations, International Journal of Environment and Geoinformatics, 8(3), 386-396, doi.10.30897/ ijegeo.914055

Benjelloun, Y., de Sigoyer, J., Dessales, H., Garambois, S., Şahin, M. (2018). Construction History of the Aqueduct of Nicaea (Iznik, NW Turkey) and its OnFault Deformation Viewed from Archaeological and Geophysical Investigations. Journal of Archaeological Science: Reports, 21, 389-400.

Bruun, P. M., Sutherland C. H. V., Carson, R. A. G. (1966). The Roman Imperial Coinage VII: Constantine and Licinius A.D. 312/3 - 337. London.

Covel, J. (1998). Voyages en Turquie 1675-1677 (texte établie, annoté et traduit par Jean-Pierre Grélois ; avec une préface de Cyril Mango). Paris: P. Lethielleu.

Çibuk, K., Gölcük, R. (2021). The Impact of the Industrialization and Urbanization on the Quantity and Diversity of Amphorae in the Museums: The Case of İzmit Gulf, International Journal of Environment and Geoinformatics, 8(2), 226-228, doi.10.30897/ijegeo.808243

Davis, L. D. (1990). The First Seven Ecumenical Councils (325-787). Their History and Theology (Theology and Life Series 21). Collegeville, Minnesota: The Liturgical Press.

Demirel S, Alpar B, Yaltırak C, Vardar D, Kurt H (2020) Northern segment of the North Anatolian Fault in the Gulf of Izmit inferred from marine magnetic anomalies. Mar Geophys Res 41:6, doi.10.1007/s11001-020-09399-6

Erginal, A. E., Erenoğlu, R. C., Yıldırım, C., Selim, H. H., Kiyak, N. G., Erenoğlu, O., Ulugergerli, E., Karabıyıkoğlu, M. (2021). Co-Seismic Beachrock Deformation of 8th Century AD Earthquake in Middle Strand of North Anatolian Fault, Lake Iznik, NW Turkey. Tectonophysics, 799, 228690, 1-8.

Gastineau, R., de Sigoyer, J., Sabatier, P., Fabbri, S. C., Anselmetti, F. S., Develle, A. L., Şahin, M., Gündüz, S., Niessen, F., Gebhardt, A. C. (2021). Active Subaquatic Fault Segments in Lake Iznik Along the Middle Strand of the North Anatolian Fault, NW Turkey. Earth and Space Science Open Archive (ESSOAr). 10.1002/essoar.10504104.1.

Gazioğlu, C. (2017). Assessment of Tsunami-related Geohazard Assessment for Coasts of Hersek Peninsula and Gulf of İzmit, International Journal of Environment and Geoinformatics, 4(2), 63-78, doi. 10.30897/ijegeo.312554

Gökaşan, E., Alpar, B., Gazioğlu, C., Yücel, Z.Y., Tok, B., Doğan, E., Güneysu, C. (2001). Active tectonics of the İzmit Gulf (NE Marmara Sea): from high resolution seismic and multi-beam bathymetry data. Marine Geology 175/1-4, 271-294.

* The format is arranged in accordance with the notion of the Archeology profession.
Hana Morel, Janna oud Ammerveld (2021). From Climate Crisis to Climate Action: Exploring the Entanglement of Changing Heritage in the Anthropocene, The Historic Environment: Policy \& Practice, doi.10.1080/17567505.2021.1957261.

Hendy F. M. (1999). Catalogue of the Byzantine Coins in the Dumbarton Oaks Collection and in the Whittemore Collection IV, Alexius I to Michael VIII, 1081-1261. Washington.

İnanan, F. (2014). Zeuksippus Tipi Seramiklerin Anadolu'daki Dağılımları. Uludağ Üniversitesi, FenEdebiyat Fakültesi, Sosyal Bilimler Dergisi, 26/1, 149-166.

Kaya, H., Çalık, MM., Şehla, C., GFAzioğlu, C., Delibal, A., Kimyonok, T. (2020). Kıyı Kentlerinde Kültür Varlıkları ve Jeoarkeoloji Çalışmaları (Beylikdüzü Örneği), Güncel Sosyal Bilimler Araștırmaları, 153-169.

Laborde L. (1838). Voyage de l'Asie Mineure. Paris.

Mango, C. (2004). Birinci Ökümenik Konsil'in Toplandığ1 Yer ve Kutsal Pederler Kilisesi. In: Akbaygil, I., İnalcık, H., Aslanapa, O. (eds.), Tarih Boyunca İznik (pp.305-312), İstanbul.

Michael, A., Attaleiatēs, M. (2012). The History (Vol. 16). Cambridge: Harvard University Press.

Öniz, H., Kaya, H., Gazioğlu, C. (2015). Geoarchaeological Researches on the Mediterranean Coast, II. Klyı ve Deniz Jeolojisi Sempozyumu, 133p.

Öztürk, K., Yaltırak, C., Alpar, B. (2009). The relationship between the tectonic setting of the Lake Iznik basin and the middle strand of the North Anatolian Fault, Turk. J. Earth Sci., 18: 209-224.

Papanikola-Bakirtzis, D. (ed.) (1999). Byzantine Glazed Ceramics - The Art of Sgraffito. Athens: Archaeological Receipts Fund.

Powell, E. (2015). Sunken Byzantine Basilica. Archaeology, January/February, 27.

Şahin, M. (2015). İznik Gölü Bazilika Kalıntısı Sualtı Yüzey Araştırması. TINA Denizcilik Arkeoloji Dergisi, 4, 33-51.

Şahin, M., Fairchild, M. R. (2018). Nicea’s Underwater Basilica. BAR, 44.6, 30-38.

Şahin, M., Tok, E., Kılıç, Ş. (2014). İznik Gölü'ndeki Batık Kilise: Deprem Kurbanı Aziz Neophytos. Aktüel Arkeoloji, 38 (Nisan), 8-10.

Veth, W. J. G. A. (2003). The Frescoes of the Ecumenical Councils in the Sistine Salon (1590) and the Catholic Conciliar Historiography (Th.D. Thesis), Pontifical University of the Holy Cross, Rome.

Yaltırak C, Ülgen UB, Zabcı C, Franz SO, Akçer Ön S, Sakınç M, Cağatay MN, Alpar B, Öztürk K, Tunoğlu C, Ünlü S (2012) Discussion: a critique of Possible waterways between the Marmara Sea and the Black Sea in the Late Quaternary: evidence from ostracod and foraminifer assemblages in lakes İznik and Sapanca, Turkey. Geo-Mar Lett 32:267274

Yıldırım F. (2014). 14. Yüzylldan Cumhuriyet Dönemi'ne Kadar Yabancl Seyyahların Gözünden Bursa Illindeki Mimari Eserler I-II. Bursa. 